\title{
KITAB KUNTARA RAJA NITI Study of the Entry of Islam in Lampung
}

\author{
Fitri Yanti Yasin', Eni Amaliah Juhro² \\ \{fitriyanti@radenintan.ac.id ${ }^{1}$, eni.amaliah@ radenintan.ac.id ${ }^{2}$ \} \\ ${ }^{1,2}$ Universitas Islam Negeri Raden Intan Lampung, PPs Universitas Islam Negeri Raden Intan Lampung, \\ Jl. ZA Pagar Alam, Labuhan Ratu, Bandar Lampung Phone: (0721) 5617070
}

\begin{abstract}
Kuntara Raja Niti is a custom book that became a reference for the customs of Lampung. mentioned in this manuscript that Kuntara Raja Niti is the book of the law in force in three regions, namely Majapahit, Padjadjaran, and Lampung. This book contains various clues to life for supporters of Lampung culture. Islam was entered to Lampung around the 15th century through the three main doors. From the three entrances of Islam, the most influential over the southbound lanes. The symbols of Islamic teachings in the Book of Kuntara Raja Niti is containing moral norms rooted in the teachings of Islam. Lampung sociaty have the nature piil-pusanggiri, juluk-adok, nemui-nyimah, nengahnyampur, sakai-sambaian. Wedding ceremonies, funerals, estate division, Bucokokh (Shave/Akikah), and circumcision ceremonies. all these qualities are the foundation of Islam.
\end{abstract}

Keywords: Kuntara Raja Niti, Lampung, Symbol of Islam

\section{Introduction}

The Kuntara Raja Niti [1] Book is a traditional book which is a reference for Lampung people's customs. This book is used in almost every sub-tribe of Lampung, both Pepadun and Pesisir. In each of the tribes (descendants) of the sub-tribe, they also admit that Kuntara Raja Niti is a Lampung traditional reference book. Despite being a traditional reference book, this manuscript is now more similar to an ancient object that was saved. Because more is stored than opened for review. A shaggy brown paperback book, stored in a special box that not just anyone can open. The book consists of two parts, the first part was written in the Lampung style of the 17th century style (the letters are more sleepy than the Lampung script used today). [2] But for the balance of adat and the general public, very few know, know and understand the contents of the moral messages contained in the Kuntara Raja Niti book. This is caused by the fact that the Book is indeed scarce or lack of information related to this book. The Kuntara Raja Niti book is believed by the user community and its supporters as a guidebook inherited from their predecessors who came from the Majapahit era:[3]

The contents of the manuscript are actually not only a matter of ceremonial customary procedures, such as wedding ceremonies, death etc. but the book contains social regulations or what is more properly called legislation. As mentioned in the manuscript, that the Kuntara Raja Niti book is a law that applies in three regions, namely Majapahit, Padjadjaran, and Lampung. As a book of laws or the basis of social law, the book is written systematically. This book contains various instructions of life for the supporters of Lampung culture. Therefore, the classic (ancient) book of Kuntara Raja Niti is seen to have its own legal logic and thoughts relevant to the past formal legal life which explicitly implies the existence of an element of 
knowledge that has a substance of ethica, [4] the classic (ancient) book of Kuntara Raja Niti is seen to have its own legal logic and thoughts relevant to the past formal legal life which explicitly implies the existence of an element of knowledge that has a substance of ethica.

From this background the researcher wants to examine the entry of Islam in Lampung and the symbols of Islamic teachings that exist in the contents of the Kuntara Raja Niti text, especially the entry of Islam in Lampung and the history of Lampung people told in the book is very full and this is still very rarely raised by the author Lampung local writers. This becomes interesting to discuss and examine because all this time the early history of the entry of Islam into Lampung was only known by word of mouth or only oral stories from generation to generation.

\section{Formulation of the problem}

Based on the background above, the writer will describe about the Kuntara Raja Niti Book namely the entry of Islam in Lampung and the symbols of Islamic teachings contained in the book. From the starting point of the description above, it can be formulated that the main problems of this study are:

1. How is the entry of Islam in Lampung in the Book of Kuntara Raja Niti?

2. What are the Symbols of Islamic Teachings in the Book of Kuntara Raja Niti?

\subsection{Purpose and Use of Research}

In accordance with the formulation of the problem, the objectives to be achieved in this study are as follows:

1. Reveal the Entry of Islam in Lampung in the Book of Kuntara Raja Niti.

2. Reveal Islamic Teachings Symbols in the Book of Kuntara Raja Niti.

\subsection{Benefits of research}

1. With this research it is hoped that it can help other researchers to learn and understand the contents of the Kuntara Raja Niti text

2. With this research it is hoped that it can help other researchers to study and absorb the development of Islamic history in Lampung in the Kuntara Raja Niti Book

3. With this research it is hoped that it can help other researchers in studying the development of Lampung culture in Lampung in particular and in Indonesia in general.

\section{Research Methodology}

The research conducted by the author is a descriptive study, the author conducts library research (Library Research). This research uses historical research method or called historical method, research method is a step or method of reconstructing the past systematically and objectively by collecting, interpreting and synthesizing data in order to uphold facts and strong conclusions. The historical methods used in this study include:

Heuristics or comprehensive data collection, Verification or testing of sources, Interpretation or interpretation of data, and Historiography or writing. The data analysis methods used by the authors in analyzing and evaluating data are descriptive method and deductive method. 


\section{Research result}

\subsection{The Entry of Islam in Lampung in the Book of Kuntara Raja Niti}

Islam entered Lampung around the 15th century through three main doors. From the west (Minangkabau) this religion entered through Belalau (West Lampung), from the north (Palembang) through Komering during the Duke of Arya Damar (1443), and from the south (Banten) by Fatahillah or Sunan Gunung Jati, through Labuhan Maringgai in Keratuan Pugung (1525).

Of the three entrances of Islam, the most influential is through the southern route. This can be seen from historical sites such as the tomb of Tubagus Haji Muhammad Saleh in Pagardewa, Tulangbawang Barat, the tomb of Tubagus Machdum in Kuala, South Telukbetung, and the tomb of Tubagus Yahya in Lempasing, Kahuripan allegedly are still descendants of Sultan Hasanuddin from Banten. In Ketapang, South Lampung, there is the tomb of Habib Alwi bin Ali Al-Idrus. [5]

The spread of Islam in Lampung predominantly through the south (Banten), does not mean it can touch the entire area in Lampung. From the north, for example, Islam easily entered from Pagaruyung (Minangkabau). From the north, Islam entered from Palembang through Komering. From the north, Islam was brought by four sons of King Pagaruyung Maulana Umpu Ngegalang Paksi. This phase is the most important part of the existence of Lampung people. The arrival of the four groups is a setback from the Kingdom of Ancient Brak or Buay Tumi, which is a Hindu of Bairawa / animism. This momentum was at the same time a milestone in the establishment of the Sekala Brak Witness or Pak Sekala Brak Paksi based on Islam. The four sons of Maulana Umpu Ngegalang Paksi were Umpu Bejalan di Way, Umung Belunguh, Umpu Nyerupa, and Umpu Pernong. These four or some of them came from Pagarruyung which meant the entry of Islam into Lampung in the XIV and XV centuries.[6]

Besides being influenced by Banten Lampung it was also influenced by the sultanate of Palembang. [7] From the south (Banten), Islam is thought to have been brought by Fatahillah or Sunan Gunung Jati through Labuhan maringgai now, precisely in Keratuan Pugung. Here, it is said, Fatahillah married Putri Sinar Alam, the daughter of Ratu Pugung. From this marriage gave birth to a child who was named Minak Kemala Ratu, who later became the forerunner to the White Blood Keratuan and lowered Radin Inten, a Lampung hero who was also a propagator of Islam on the coast. [8] The relics of the XV M. [9] century as a sign of Islam entered there include the Koran ancient handwriting and the Banten-Lampung Agreement. The brotherhood agreement was written in Arabic. In addition, other evidence is the Customary Law or Kuntara Raja Niti. The law is written in two versions, namely Banten language with Arabic script and Lampung language with ka-ga-nga. Islam entered through Aceh, this opinion was strengthened by the discovery of tombstones in Muara Batang village (Palas sub-district of South Lampung) tombstones at the tomb of Wonosobo, South Lampung also had aceh style. There is a tombstone in the form of the same motif as the tombstone Malik Al Saleh in Pasai from 1297.[10]

Islam that enteres Krui might not only come from one direction that come from WestSumatera but there might also be those who came from Banten. The entry of Islam in Tulang Bawang is estimated since the 16th century one of the sons of the area came from the Pagardewa village named Diman Kemala Bumi known as Minak Pati Prajurit. in addition there is another Banten's man named Haji Muhammad Saleh who spread Islam in Pagardewa.[11] 
Palembang Sultanate. Thus the Islamization of Lampung from the XIII century to the The entry of Islam in the area of Penggala Tulang Bawang brought by Islamic traders from sixteenth century. In Belalau, there is the tomb of Raja Belalu and his warlords totaling 7 graves. Based on the many evidences stated above it is clear that the early centuries of the development of Islam in Lampung was also the period of the development of Banten's influence over Lampung. it was explained that the entry of Islam in the coastal area, starting with the arrival of Fatahillah in Keratuan Pugung (Muara Sekampung) in the mid-15th century.

\subsection{Symbols of Islamic Teachings in the Book of Kuntara Raja Niti}

The symbols of Islamic teachings in the Kuntara Raja Niti Book which contain moral norms that are based on Islamic teachings, namely:

\subsubsection{The Philosophy of Living in Ulun Lampung}

Lampung's Ulun Life Philosophy is contained in the Kuntara Raja Niti book, namely:

1. Piil-Pusanggiri (ashamed to do shameful work according to religion and have dignity)

2. Juluk-Adok (has personality according to the traditional title he bears)

3. Nemui-Nyimah (visiting each other to be friendly and welcoming guests)

4. Nengah-Nyampur (active in social relations and not individualistic)

5. Sakai-Sambaian (mutual assistance and mutual assistance with other community member[12]

The properties above are symbolized by the 'five flower decoration flower' on the symbol of Lampung Province. The characteristics of the Lampung people are also expressed in adi-adi (rhymes)

Tandani ulun Lampung, wat piil-pusanggiri Mulia heno sehitung, wat liom ghega dighi Juluk-adok gham pegung, nemui-nyimah muaghi Nengah-nyampugh mak ngungkung, sakai-Sambaian gawi. [13]

All of these characteristics are the foundation of Islam according to the Book of Kuntara Raja Niti

A. Pi'il Pesenggikhi.

B. Sakai Sambaian.

C. Meet Nyimah.

D. Nengah Nyampukh.

E. Bejuluk Adok [14]

The values and legal standards that underlie it are cultural customs that are rooted in the principles of Islamic law. As a Muslim in every action in daily business or association, of course guided by the Islamic moral principle, namely prioritizing expediency, honesty, kindness, truth and responsibility.

Characteristics of Lampung society is to prioritize the preservation of their good name, far from blemishes and insults as outlined in Islam. [15] This unique characteristic can be used as an important capital base for efforts to establish national identity. There are eight elements of the spirit of faith that must be practiced in this life, namely: (1) Tawhid (fear of God), (2) moral (good morals), (3) respect for parents, (4) sincere / sincere, (5) ) 
useful knowledge, (6) able to control lust, (7) opinion (identity), and (8) exemplary in action.

\subsubsection{Wedding ceremony}

In Lampung society, the marriage tradition is a rule that has been practiced since ancient times and as a custom to enter into a contract (agreement) between a man and a woman. The purpose of marriage is intended so that sexual relations between men and women become lawful and lawful as husband and wife. Descriptions of Islamic traditions in Lampung Pubian and Coastal culture include the procedure of giving and taking girls (cuddling, cuckering muli), namely wooing (Lampung language "Rasan Tuha"). And sebambang: what can be explained is based on the agreement between male parents and female parents. In the implementation of marriage ceremonies are often done to build relationships between kinship parents. As intended, "marriages in a sense of God will always be carried out in a ceremony or propose to a bride". [16]

\subsubsection{Funerals}

The ceremony to solicit corpses is carried out in accordance with Islamic teachings. Before the corpse is performed, several ceremonies are performed. Before the stretcher of the corpse arrived at the front door is usually done throwing rice rice with the intention to be safe and happy by God after a big throw, said the words of the release of the corpse whose contents apologize for the deceased of the deceased while still alive. After the ceremony, the bodies were released and then they were put in the mosque, in the munasah or at home. In some places, especially in villages, people who pray are given alms by heirs. [17]

In addition to the death ceremony above, there are several events that take place after a person dies, namely planting stones buried on the seventh or fortieth day, fidiyah shalat for almarhum especially during his lifetime not performing prayers, festive haul / annual kifarat oath to corpses, activities to guard the grave for a week, aqiqah is performed on the seventh night for small children.

\section{Takziah}

In the tradition of the community, the program of takziah is held from the first day until the seventh day after that on days 15, 40, and 100 they hold a ceremony Tahlilan to read Yasin, al ikhlas, al falq, an-Nas, early surah al Baqoroh, ayat kursi, and the end of surah al-Baqarah after that reciting tahlil and ending with recitation of prayer. It's just that tahlil events are common in the Pubiyan indigenous people, like the field people in general, are read in the typical style of North Sumatra, with a friendly sikhah song. Takziyah on the first day until the third day, usually only served snacks, but on days 7, 15, 40, and 100 held a meal together called "Kenduri". [18]

\subsubsection{Recite the Grave}

After a corpse is buried, in the adat community there is still a tradition of reciting the grave, there are two kinds of tradition:

1. After the body is buried, then the Koran recitation is buried usually done for three days and three nights.

2. The family every Friday morning (after dawn prayer) comes to the tomb with the help of improvised lighting tools, the heirs sit beside the tomb and read the Yasin letter which ends with prayer. 


\subsubsection{Distribution of Inheritance}

Heirs and heirs are in a relationship between the two, the kinship or marriage rope. Thus the facts show that in terms of the distribution of wairs property, it turns out that inheritance law according to Islam has influenced customary law, at least giving a strong position to the principle of justice or giving a substitutive concept that has been accepted in customary law. If someone leaves the world then the procedure of division according to the Islamic way is based on faraid science Implementation is usually done 100 days after death.

\subsubsection{Bucokokh (Shaving / Akikah)}

Babies that are 40 days old must be held safely by shaving a few strands of their hair. This activity is carried out by inviting family friends, acquaintances of neighbors and so on to provide prayers for the safety of the baby in the future.

\subsubsection{Circumcision Ceremony (Circumcision)}

Boys are usually the eldest, who will be circumcised early in the morning have been bathed using white talesan (Talosan) and then fed on roasted chicken. This ceremony is held on a large scale if the oldest son will be circumcised and has finished studying, plus the replacement ceremony for his brother or sister. The goal so that one day after the adult child is kind, good at building a household and good at cooking.[17]

\section{Conclusion}

The classic book (ancient) Kuntara Raja Niti is seen to have its own legal logic and thoughts relevant to the past formal legal life which explicitly implies the existence of an element of knowledge that has a substance of ethical value. As a book of laws or the basis of social law, the book is written systematically. This book contains various instructions of life for the supporters of Lampung culture. Islam entered Lampung through culture and trade routes. Evidence of the existence of Islamic civilization in Lampung is marked by the existence of historic tombs, historic mosques, and historical places including books and poetry and Islamic kingdoms in Lampung. Islam is also closely related to the customs and culture of Lampung. As a forerunner of the Lampung tribal community, the symbols of Islamic teachings according to the Kuntara Raja Niti book are that Lampung people all these qualities are the foundation of Islam.

\section{Reference}

[1] A. D. I. Utami, W. Warto, and S. Sariyatun, "The Strategy to Improve Cultural Awareness Through Historical Learning Based on Kitab Kuntara Raja Niti," Int. J. Multicult. Multireligious Underst., vol. 5, no. 4, pp. 90, May 2018.

[2] S. Andika Dian Ifti Utami, Warto, "Penguatan Pendidikan Karakter Melalui Pembelajaran Sejarah Berbasis Kitab Kuntara Raja Niti,” J. Pendidik. Sej. Indones., pp.68, 2018.

[3] K. D. Lampung, "Dimensi aksiologis filsafat hidup."pp, 282.

[4] L. Mulyadi, "Eksistensi Hukum Pidana Adat Di Indonesia: Asas, Pengkajian Teori, Norma Prosedurnya," J. Huk. dan Peradil., pp. 245, 2012.

[5] M. Wijayati, "Jejak Kesultanan Banten di Lampung Abad XVII (Analisis Prasasti 
Dalung Bojong),” Anal. J. Stud. Keislam., pp. 385, 2014.

[6] A. F. Nurdin, "Budaya Muakhi Dan Pembangunan Daerah Perspektif Filsafat Sosial Pada Komunitas Adat Pubian Di Lampung," Alqalam, vol. 26, no. 3, pp. 40-41, 2009.

[7] D. Ciciria, "Siger Sebagai Wujud Seni Budaya Pada Masyarakat Multietnik di Provinsi Lampung," Panggung, vol. 25, no. 2, pp. 196, Sep. 2015.

[8] L. Nuralia and I. Imadudin, "Pengaruh Akulturasi Budaya Terhadap Dualisme Sistem Ekonomi Masyarakat Kampung Tua di Kecamatan Abung Timur, Kabupaten Lampung Utara," Patanjala J. Penelit. Sej. dan Budaya, vol. 9, no. 1, pp. 72, Mar. 2017.

[9] M. Halwi Dahlan, "Perpindahan Penduduk dalam Tiga Masa: Kolonisasi, Kokuminggakari, dan Transmigran di Provinsi Lampung (1905-1979),” Patanjala J. Penelit. Sej. dan Budaya, pp. 339, 2014.

[10] E. Sofia, "Pemakaian Bahasa Lampung di Daerah Rajabasa," Lokabahasa, vol. 6, no. 1, pp. 39, Apr. 2015.

[11] J. B. Kingston, "Manipulating Tradition: The State, Adat, Popular Protest, and Class Conflict in Colonial Lampung," Indonesia, vol. 51, pp. 24, Apr. 1991.

[12] Hi. Yusuf, "Nilai-nilai Islam dalam Falsafah Hidup Masyarakat Lampung," Kalam, vol. 10, no. 1, pp. 173, Feb. 2017.

[13] F. Utama, "Piil Pesenggiri Dalam Masyarakat Lampung: Antara Instrumen Bina Damai Atau Dalih Kekerasan,” Inov. Pembang. J. Kelitbangan, pp. 118, 2019.

[14] F. Nurdin, "Integralisme Islam dan Kontribusi Budaya Muakhi Bagi Peradaban Masyarakat Serta Relevansi Nilai-Nilai Filosofis Budaya Lokal dan Pembangunan Masyarakat Lampung," Al-Adyan J. Stud. Lintas Agama, vol. 14, no. 1, pp. 40, Aug. 2019.

[15] F. Fachruddin, "Falsafah Piil Pesengiri sebagai Kearifan Kota Lampung Teraktualisasi Melalui Pendidikan Non Formal," Perspekt. Ilmu Pendidik., vol. 15, no. VIII, pp. 7175, Apr. 2007.

[16] A. Isnaeni and K. M. Hakiki, "Simbol Islam dan Adat dalam Perkawinan Adat Lampung Pepadun,” Kalam, vol. 10, no. 1, pp. 196, Feb. 2017.

[17] L. Mulyadi, "Eksistensi Hukum Pidana Adat di Indonesia : Pengkajian Asas, Norma, Teori, Praktik dan Prosedurnya," J. Huk. dan Peradil., vol. 2, no. 2, p. 386, Jul. 2013.

[18] S. Windya Sari, "Pergeseran Nilai-Nilai Religius Kenduri Dalam Tradisi Jawa Oleh Masyarakat Perkotaan," Candi,pp. 7, 2012. 